\title{
EVALUATION OF ANTIOXIDANT, ANALGESIC AND ANTI-INFLAMMATORY PROPERTIES OF SEDUM ADENOTRICHUM
}

\author{
DIL NAZ ${ }^{1,2}$, ALI MUHAMMAD ${ }^{1}$ and ALAM ZEB ${ }^{2, *}$ \\ 'Department of Zoology, Islamia College University, Peshawar, \\ Khyber Pakhtunkhwa, 25000, Pakistan. \\ ${ }^{2}$ Department of Biochemistry, University of Malakand, Chakdara, \\ Khyber Pakhtunkhwa, 18800, Pakistan
}

\begin{abstract}
Sedum adenotrichum crude extract have been evaluated for in vitro antioxidant activities and in vivo analgesic and anti-inflammatory potentials. Results showed strong ABTS, $\mathrm{H}_{2} \mathrm{O}_{2}$, and DPPH free radical scavenging activities. The extract caused a significant decline of acetic acid-induced abdominal constrictions whereas, significantly inhibited both phases of formalin-induced paw licking responses. In tail immersion assay a significant analgesic response of $58.65 \%$ was observed at $75 \mathrm{~min}$ at a dose of $125 \mathrm{mg}$ and $60.67 \%$ at $90 \mathrm{~min}$ at a dose of $250 \mathrm{mg}$. The morphine exhibited dominant activity at $60 \mathrm{~min}$ after treatment of $84.86 \%$. Animals treated with naloxone produced a significant reduction in analgesic potentials of morphine and extract. In the carrageenan-induced model for anti-inflammatory activity, edema formation was inhibited by the extract in the $3^{\text {rd }}$ hour at a dose of 100 and $200 \mathrm{mg}$, by 50.75 and $52.49 \%$, respectively in a dose-dependent manner.
\end{abstract}

Keywords: Sedum adenotrichum, analgesic, antioxidant, anti-inflammatory

Antioxidants are used for the protection of living cells from the attacks of free radicals. These free radicals are molecules or atoms and are very reactive because of the unpaired electrons. The living body produces traces of oxidants normally during metabolism that are beneficial to the body while destroying micro-organisms. However, oxidants in huge quantities are injurious to the body (1). These reactive oxygen species (ROS) have been concerned with more than 100 ailments, including heart diseases, cancer, arteriosclerosis, acquired immunedeficiency syndrome, malaria, stroke, and diabetes with significant involvement in pain generation and tissue damage or inflammation (2).

Pain is an emotional or unpleasant sensory experience leading to damage of tissues. It is typically considered as a warning sign which elicits impulse and conscious avoidance reaction in protecting the body from potential harms (3). There is a complex perception of pain and is under the control of many variables. The primary role of the sensory system is guarding and keeping up pain homeostasis. It is achieved via identification, localization, and recognition of the damaging processes in the tissue. Although pain is primarily a defensive mechanism that is produced while the tissue is being damaged and made an individual demonstrate response and eradicate the causative stimulant, however, during many circumstances it disturbs social functioning and decreases life quality (4). On the other hand, inflammation is a biological complex response of vascular tissues to harmful stimuli. It is a protective immune vascular response that involves molecular mediators, blood vessels, and immune cells. The typical signs of acute inflammation are pain, heat, redness, swelling, and loss of function (5). In many cases like osteoarthritis, rheumatoid arthritis and atherosclerosis have no resolution and chronic inflammation develops lasting for the life of the individual (6).

Drugs of natural origin are an important source for the treatment of many diseases. Nowadays, the use of alternative medicine and particularly botanicals have been increasing rapidly worldwide, mostly because of their minimal side effects as compared to chemical therapeutic agents (7). Though plants

* Corresponding author: e-mail: azebuom@gmail.com 
have been used as a source of analgesic and antiinflammatory agents since ancient times, the discovery of chemical agents has led to their neglect for a long time, but fortunately, for various reasons, many people are reverting to herbal medicines.

The genus Sedum is the most species-rich and taxonomically complex member of the family Crassulaceae. Its members are widely distributed in the world (African region) (8) including Pakistan. Most species of this genus are used in the treatment of infected wounds, ulcers, as hypotensive, anti-inflammatory, antioxidant, anti-nociceptive, antitumor, and hepatoprotective in traditional medicine (9). Several species in this genus possess high economic values as medicines, food, and ornamentals. Recently, Sedum adenotrichum has in vitro and in vivo anti-diabetic properties (10). Some are toxic or allergenic which can adversely affect humans and animals (11). Apart from other traditional uses, Sedum adenotrichum is known for its use in rashes, skin eruptions, blisters, burns, constipation, and dyspepsia (12). However, there is a lack of literature regarding its phytochemical composition and medicinal properties. In our recent study (10), we have shown the phenolic profile of the plant. The present study was aimed to explore the scientific basis of the traditional use of the species for possible in vitro antioxidant and in vivo antinociceptive and antiinflammatory potentials. Keeping in view the importance of the genus Sedum and its phytochemicals, Sedum adenotrichum also known as Rosularia adenotrichum is selected for the present study.

\section{EXPERIMENTAL}

\section{Plant collection}

Sedum adenotrichum whole plant was collected from Malakand, and shade dried at room temperature. The plant was identified by Prof. Dr. Jahandar Shah, Taxonomist, University of Malakand. A reference specimen No. SA-11-2015 was deposited to the herbarium, University of Malakand. The dried material $(600 \mathrm{~g})$ was finally grounded and subjected to maceration in methanol $(6 \mathrm{~L})$ for three weeks at room temperature $\left(25 \pm 2^{\circ} \mathrm{C}\right)$ followed by solvent evaporation. The solvent was completely evaporated using an evaporator (Heidolph, Germany) and the gummy extract was poured into separate bottles and labeled. The phenolic composition of the extract was studied using HPLC-DAD and the results were recently reported (10).

\section{Chemicals and drugs}

Acetic acid, carrageenan (Sigma-Aldrich, Germany) formalin, and Tween-80 (Merck,
Germany) were used. Standard drugs, diclofenac sodium, indomethacin, morphine, and naloxone were obtained from the local market.

\section{Animals}

Swiss Albino mice (18-23 g) and Wister Albino rats (150-170 g) were obtained from the National Institute of Health, Islamabad. They were kept according to standard conditions with open access to water and standard diet at the University of Malakand's animal house. The animals were kept fasting for 12-18 $\mathrm{h}$ before starting the experiment. The protocols of the experiment were approved by the Ethical Committee of Pharmacy Department via No: E-SA-11-2009 and ensured its accomplishment with provisions of the "Animal Bye-Laws 2008, Scientific Procedures Issue-I of the University of Malakand". The studies were finally approved by Advanced Studies and Research Board (ASRB), of the Islamia College University, Peshawar, in its $20^{\text {th }}$ meeting.

\section{Acute toxicity}

The plant extract was suspended in tween-80 (2\%) to determine acute toxicity in mice. Different doses of extract $(10,100$, and $1000 \mathrm{mg} / \mathrm{kg}$ ) were given by i.p route to six groups of mice $(n=6)$ in $1^{\text {st }}$ phase and 1500 and $2000 \mathrm{mg} / \mathrm{kg}$ body weight in $2^{\text {nd }}$ phase and observed for $30 \mathrm{~min}$ and then six-hourly examination for $24 \mathrm{~h}$. The animals were kept for 14 days for any behavioral changes and the manifestation of the extract toxicity (13).

\section{Antioxidant activity \\ DPPH radical scavenging assay}

The plant samples were tested for antioxidant activity via its ability to scavenge DPPH free radicals. The crude extracts at the concentration of 40 , $60,80,100$, and $200 \mathrm{mg} / \mathrm{mL}$ were mixed with $1 \mathrm{~mL}$ $(90 \mu \mathrm{M})$ solution of DPPH respectively and made 4 $\mathrm{mL}$ final volume with methanol. The absorbances of blank and test solutions were noted at room temperature at $512 \mathrm{~nm}$ using a UV-visible spectrophotometer. Ascorbic acid was used as a positive control in the concentration range of 62.5 to $1000 \mu \mathrm{g} / \mathrm{mol}$. The $\mathrm{IC}_{50}$ values, representing test sample concentration that caused $50 \%$ DPPH radical neutralization was calculated from the plot of percentage inhibition $v s$ concentrations (14).

\section{ABTS assay}

The plant samples were tested for antioxidant potentials using its ability to scavenge ABTS free radical cations which resulted in a decline in 
absorbance at $734 \mathrm{~nm}$ (14). Briefly, a $7 \mathrm{mM}$ solution of ABTS was mixed with a $2.45 \mathrm{mM}$ solution of $\mathrm{K}_{2} \mathrm{~S}_{2} \mathrm{O}_{4}$ and incubated for $14 \mathrm{~h}$ in dark at room temperature, which gave a solution of dark color having ABTS cation radical. For adjusting the absorbance at $734 \mathrm{~nm}, 0.01 \mathrm{M}$ phosphate buffer ( $\mathrm{pH} \mathrm{7.4)}$ was added to the ABTS cation radical solution. The ABTS solution of $3 \mathrm{~mL}$ was added to $300 \mu \mathrm{L}$ test samples to find out its radical scavenging ability. The decrease in absorbance after one minute of mixing the solutions was measured using a spectrophotometer. Ascorbic acid in different concentrations was used as a positive control. All the readings were taken in triplicate. Calculated the \% scavenging as: ABTS Inhibition $(\%)=\frac{\text { Absorbance of Control }- \text { Absorbance of Sample } \times 100}{\text { Absorbance of Control }}$

\section{$\mathrm{H}_{2} \mathrm{O}_{2}$ scavenging assay}

The plant samples were tested for antioxidant potentials via its ability to scavenge hydrogen peroxide radicals by the method described recently (14). Hydrogen peroxide $(40 \mathrm{mM})$ solution was prepared in phosphate buffer $(\mathrm{pH}$ 7.4). A solution of hydrogen peroxide was added to the extract in a concentration range of $62.5-1000 \mu \mathrm{g} / \mathrm{mL}$ and incubated for $10 \mathrm{~min}$. The absorbance of the mixture was measured at $560 \mathrm{~nm}$ through a UV-visible spectrophotometer against the blank having phosphate buffer with no hydrogen peroxide. The experiment was repeated thrice. The $\%$ scavenging activity was calculated.

\section{Writhing tests}

Anti-nociceptive effects of the 125 and $250 \mathrm{mg}$ crude extract were assessed using mice animal models. The different doses (125 and $250 \mathrm{mg} / \mathrm{kg}$ ) suspended in tween-80 (2\%) were dispensed orally and diclofenac sodium $(10 \mathrm{mg})$ was given intraperitoneally to respective groups of mice $(n=6)$. Tween-80 (2\%) in normal saline was dispensed to the control group. Acetic acid $(1 \% \mathrm{v} / \mathrm{v}, 0.1 \mathrm{~mL})$ was administered i.p after $30 \mathrm{~min}$. After 3 minutes of acetic acid injection, the numbers of turning of trunk, abdominal constriction, and hind legs extension for 30 minutes test period were noted (15).

\section{Formalin tests}

Formalin induced paw licking reaction of mice was assessed in this test. Formalin $(20 \mu \mathrm{L})$ was administered ( $1 \%$ in $0.9 \%$ normal saline, s.c) in the hind paw dorsal region and observed licking response while placing mice in the transparent box. The reaction time $(\mathrm{sec})$ duration of paw biting or licking was noted in the $1^{\text {st }}$ phase $(0-5 \mathrm{~min})$ and the second phase (15-30 min). The crude extracts at doses of 125 and $250 \mathrm{mg} / \mathrm{kg}$ were given subcutaneously and $10 \mathrm{mg} / \mathrm{kg}$ of indomethacin (i.p) were also given to three groups, before $30 \mathrm{~min}$ of formalin injection. The control group received $0.1 \mathrm{~mL} / 10 \mathrm{~g}$ of the vehicle. The reaction time ( $\mathrm{sec}$ ) of each group was noted with control and demonstrated as percent inhibition (16).

\section{Tail immersion tests}

The crude extract was tested for central antinociceptive activity in Albino mice. Animals were divided into various groups among which two received 125 and $250 \mathrm{mg}$ of crude extract orally. One group received vehicle (tween-80, 2\%) i.p 30 minutes before testing and morphine $(5 \mathrm{mg}$ ) and naloxone at $2 \mathrm{mg}$ (i.p), 15 minutes before testing. The latency time of mice tail deflection was recorded by immersing $1-2 \mathrm{~cm}$ tail in warm water $(53 \pm$ $\left.1^{\circ} \mathrm{C}\right)(17)$.

\section{Anti-inflammatory activity}

Wister albino rats model was used for the carrageenan-induced paw edema model as per reported protocols (18). The crude extract was given orally to overnight fasted animals $(n=6)$ at doses of 50, 100, and $200 \mathrm{mg} / \mathrm{kg}$. Indomethacin $(10 \mathrm{mg} / \mathrm{kg})$ was given to one group, which served as standard. After 30 min, all groups were given carrageenan $(1 \%, 50 \mu \mathrm{L}$, s.c) solution in the left hind paw (planter region). The mean volume of paw after every $1 \mathrm{~h}$ for $5 \mathrm{~h}$ was measured using a digital plethysmometer and treated and untreated control groups were compared. Percent of paw edema inhibition was noted.

\section{Statistical analysis}

Expressed all the data as mean with standard deviation (SD). Analysis of variance and with post hoc, Dunnett's test was performed with GraphPad Prism 5 software.

\section{RESULTS}

\section{Polyphenolic composition of the extract}

The methanolic extract of Sedum contains phenolic compounds at the lower concentration of below $100 \mu \mathrm{g} / \mathrm{g}$ of quinic acid, p-hydroxybenzoic acid, gallic acid, salicylic acid, catechin, 3-Ocoumaroylquinic acid, and naringenin. Kaempferol3-O-sophoroside, quercetin-3,4-diglucoside-3-(6feruloyl glucoside), quercetin-3-(p-coumaroyl glucoside)-7-glucoside, quercetin-3-(p-coumaroyldiglucoside)-7-glucoside, diosmetin-7-rutinoside, triferuloyl-diglucoside, kaempferol-3-(p-coumar- 
oyl-glucoside)-7-glucoside, kaempferol-3,7-diglucoside, kaempferol-3-(p-coumaroyl-diglucoside)-7glucoside and 4-caffeoyl-5-coumaroylquinic acid were major compounds as reported in our recent work (10). Three phenolic compounds namely kaempferol-3- $O$-sophoroside $(3.36 \mathrm{mg} / \mathrm{g})$, vitexin6-malonyl-2-xyloside (2.1 mg/g), quercetin-3,4diglucoside-3-(6-feruloyl glucoside) $(1.8 \mathrm{mg} / \mathrm{g})$ and diosmetin-7-rutinoside $(1.6 \mathrm{mg} / \mathrm{g})$ were present in significantly higher amounts.

\section{In vivo acute toxicity}

In vivo acute toxicity test of the extract showed no gross, physical, and behavioral changes for $24 \mathrm{~h}$ and no mortality occurred in the next 14 days. Since the extract at a dose of $2000 \mathrm{mg} / \mathrm{kg}$ didn't show any mortality in mice so it was considered to be comparatively safe, during the study it was observed that the systemic administration of the compounds didn't produce any sedation, alteration in locomotor activity or motor dysfunction in animals.

\section{Antioxidant activities}

It is clear from the results of DPPH free radical scavenging activity, the extract exhibited an excel- lent antioxidant activity in a dose-dependent way. It showed an activity of $35.0 \%$ at the lowest dose of 62.5 and $68.1 \%$ at $1000 \mathrm{mg} / \mathrm{kg}$ dose, reaching nearly to that of the standard ascorbic acid. The IC50 values of DPPH inhibition were higher than standard ascorbic acid. The extract possesses antioxidant activity in a dose-dependent way (Table 1).

The ABTS free radical scavenging activity of the extract showed good scavenging activity of $52.6 \%$ at the highest concentration of $1000 \mu \mathrm{g} / \mathrm{mL}$. Similarly, in $\mathrm{H}_{2} \mathrm{O}_{2}$ scavenging activity, the sample showed an activity starting from 21.06 at 62.5 $\mu \mathrm{g} / \mathrm{mL}$ and reached 47.9 at the highest dose of 1000 $\mu \mathrm{g} / \mathrm{mL}$ as shown in Table 1 . The IC50 values of ABTS inhibition were lower $(239.8 \mu \mathrm{g} / \mathrm{mL})$ than standard ascorbic acid $(312.3 \mu \mathrm{g} / \mathrm{mL})$. Similarly, the results of the $\mathrm{H}_{2} \mathrm{O}_{2}$ inhibition (\%) showed lower inhibition as compared to the corresponding ascorbic acid doses. The IC50 values of the extract were lower than $229.1 \mu \mathrm{g} / \mathrm{mL}$ than ascorbic acid standard.

\section{Analgesic activity}

The plant extract caused significant inhibition of analgesic response induced via acetic acid with a maximum effect of $57.4 \%(\mathrm{p}<0.01)$ and $64.7 \%(\mathrm{p}<0.001)$

Table 1. Antioxidant activities of the Sedum adenotrichum extract.

\begin{tabular}{|c|c|c|c|c|c|c|}
\hline \multirow{2}{*}{$\begin{array}{c}\text { Dose } \\
(\mu \mathrm{g} / \mathrm{mL})\end{array}$} & \multicolumn{2}{|c|}{ DPPH inhibition (\%) } & \multicolumn{2}{c|}{ ABTS inhibition (\%) } & \multicolumn{2}{c|}{$\mathrm{H}_{2} \mathrm{O}_{2}$ inhibition (\%) } \\
\cline { 2 - 7 } & Extract & A. acid & Extract & A. acid & Extract & A. acid \\
\hline 62.5 & $35.0 \pm 2.1$ & $61.1 \pm 0.7$ & $28.2 \pm 1.9$ & $66.2 \pm 0.2$ & $21.0 \pm 2.2$ & $69.4 \pm 0.8$ \\
\hline 125 & $36.6 \pm 3.2$ & $64.27 \pm 0.9$ & $34.6 \pm 1.5$ & $69.2 \pm 0.4$ & $29.2 \pm 2.1$ & $72.2 \pm 0.6$ \\
\hline 250 & $42.1 \pm 1.9 *$ & $69.61 \pm 0.5$ & $40.9 \pm 2.2 *$ & $74.1 \pm 0.7$ & $34.1 \pm 1.9 *$ & $77.3 \pm 0.3$ \\
\hline 500 & $58.4 \pm 2.3 * *$ & $76.20 \pm 1.5$ & $46.9 \pm 2.2 * *$ & $81.1 \pm 0.9$ & $43.8 \pm 2.2 * *$ & $84.1 \pm 0.7$ \\
\hline 1000 & $68.1 \pm 1.9 * *$ & $82.33 \pm 0.8$ & $52.6 \pm 1.8 * *$ & $87.2 \pm 1.5$ & $47.9 \pm 2.7 * *$ & $89.4 \pm 0.4$ \\
\hline $\mathrm{IC}_{50}$ & 374.4 & 303.8 & 239.8 & 312.3 & 229.1 & 301.0 \\
\hline
\end{tabular}

DPPH, diphenyl picrylhydrazyl radical; ABTS, 2,2'-azino-bis(3-ethylbenzothiazoline-6-sulfonic acid; A. acid, ascorbic acid; $\mathrm{IC}_{50}$, the concentration of an inhibitor where the response is reduced by half. All values are expressed as mean with standard deviation (SD) for each group. *Significant difference compared with the acetaminophen group $(\mathrm{p}<0.05)$. **Significant difference compared with the acetaminophen group $(\mathrm{p}<0.01)$.

Table 2. Acetic acid-induced analgesic activity data of Sedum adenotrichum extract.

\begin{tabular}{|l|c|c|}
\hline \multicolumn{1}{|c|}{ Treatment (dose) } & Writhes & \% inhibition \\
\hline Control & $78.6 \pm 7.6$ & --- \\
\hline Extract $(125 \mathrm{mg})$ & $33.3 \pm 1.2^{* *}$ & 57.4 \\
\hline Extract $(250 \mathrm{mg})$ & $27.8 \pm 1.1^{* * *}$ & 64.7 \\
\hline Diclofenac sodium $(10 \mathrm{mg})$ & $9.8 \pm 0.3^{* * *}$ & 87.4 \\
\hline
\end{tabular}

Values expressed as mean with standard deviation (SD) of $\mathrm{n}=6$. ** $\mathrm{p}<0.01$, ***p $<0.001$ as compared with control. 
Table 3. Analgesic activity (Tail flick method) of Sedum adenotrichum extract.

\begin{tabular}{|c|c|c|c|c|c|c|}
\hline \multirow{2}{*}{$\begin{array}{c}\text { Treatment/ } \\
\text { Dose }\end{array}$} & \multicolumn{6}{|c|}{ Tail Flick (sec) / Response (\%) } \\
\hline & $15 \mathrm{~min}$ & $30 \mathrm{~min}$ & $45 \mathrm{~min}$ & $60 \mathrm{~min}$ & $75 \mathrm{~min}$ & $90 \mathrm{~min}$ \\
\hline Control & $1.17 \pm 0.9$ & $1.32 \pm 0.5$ & $1.47 \pm 1.2$ & $1.39 \pm 1.7$ & $1.29 \pm 1.7$ & $1.38 \pm 1.5$ \\
\hline Extract $125 \mathrm{mg}$ & $\begin{array}{c}1.54 \pm 1.1^{*} \\
24.0 \%\end{array}$ & $\begin{array}{c}1.92 \pm 0.8 * \\
31.2 \%\end{array}$ & $\begin{array}{c}2.44 \pm 0.3^{* *} \\
39.7 \%\end{array}$ & $\begin{array}{c}2.91 \pm 0.8 * * \\
52.2 \%\end{array}$ & $\begin{array}{c}3.12 \pm 0.5^{* *} \\
58.6 \%\end{array}$ & $\begin{array}{c}3.31 \pm 0.9 * * * \\
58.3 \%\end{array}$ \\
\hline Extract $250 \mathrm{mg}$ & $\begin{array}{c}1.51 \pm 1.4^{*} \\
22.5 \%\end{array}$ & $\begin{array}{c}1.95 \pm 0.2 * \\
32.3 \%\end{array}$ & $\begin{array}{c}2.76 \pm 1.2 * * \\
46.7 \%\end{array}$ & $\begin{array}{c}3.09 \pm 0.4 * * * \\
55.0 \%\end{array}$ & $\begin{array}{c}3.28 \pm 1.3^{* * * *} \\
60.6 \%\end{array}$ & $\begin{array}{c}3.41 \pm 0.9 * * * \\
59.5 \%\end{array}$ \\
\hline $\begin{array}{c}\text { Standard } \\
\text { Morphine } 5 \mathrm{mg}\end{array}$ & $\begin{array}{c}2.31 \pm 1.0 * * \\
49.3 \%\end{array}$ & $\begin{array}{c}3.16 \pm 0.2 * * \\
58.2 \%\end{array}$ & $\begin{array}{c}6.78 \pm 0.9 * * * \\
78.3 \%\end{array}$ & $\begin{array}{c}9.18 \pm 0.6^{* * * *} \\
84.8 \%\end{array}$ & $\begin{array}{c}7.47 \pm 1.5 \text { *** } \\
82.7 \%\end{array}$ & $\begin{array}{c}7.11 \pm 0.7 * * * \\
80.5 \%\end{array}$ \\
\hline $\begin{array}{l}\text { Extract } 125 \mathrm{mg} \\
+ \text { Naloxone } 2 \mathrm{mg}\end{array}$ & $0.76 \pm 0.9$ & $0.97 \pm 0.6$ & $1.25 \pm 0.1$ & $1.43 \pm 1.7$ & $1.58 \pm 0.5$ & $1.68 \pm 0.9$ \\
\hline $\begin{array}{l}\text { Extract } 250 \mathrm{mg} \\
+ \text { Naloxone } 2 \mathrm{mg}\end{array}$ & $0.79 \pm 1.7$ & $0.92 \pm 1.1$ & $1.41 \pm 0.2$ & $1.53 \pm 2.5$ & $1.67 \pm 0.6$ & $1.8 \pm 1.5$ \\
\hline $\begin{array}{l}\text { Morphine } 5 \mathrm{mg} \\
+ \text { Naloxone } 2 \mathrm{mg}\end{array}$ & $1.21 \pm 1.4$ & $1.24 \pm 1.1$ & $1.39 \pm 1.2$ & $1.27 \pm 1.6$ & $1.33 \pm 0.9$ & $1.35 \pm 1.4$ \\
\hline
\end{tabular}

Data are mean with SD $(n=6) . * p<0.05, * * p<0.01$ and $* * * p<0.001$ upon comparing to control; one way ANOVA followed by Dunnetts test: compared all vs control test.

Table 4. Formalin-induced paw-licking response of the extract of Sedum adenotrichum.

\begin{tabular}{|c|c|c|c|c|}
\hline \multirow{2}{*}{ Treatment (Dose) } & \multicolumn{2}{|c|}{ Licking time Sec } & \multicolumn{2}{|c|}{ Inhibition $\%$} \\
\hline & $1^{\text {st }}$ Phase & $2^{\text {nd }}$ Phase & $1^{\text {st }}$ Phase & $2^{\text {nd }}$ Phase \\
\hline Control & $48.6 \pm 2.2$ & $72.3 \pm 1.9$ & ---- & ---- \\
\hline Extract (125 mg) & $26.6 \pm 2.0^{* *}$ & $27.6 \pm 2.7 * * *$ & 45.1 & 61.7 \\
\hline Extract $(250 \mathrm{mg})$ & $22.7 \pm 0.9 * * *$ & $21.7 \pm 0.8 * * *$ & 53.2 & 69.9 \\
\hline Indomethacin $(10 \mathrm{mg})$ & $38.5 \pm 1.3$ & $17.3 \pm 0.9 * * *$ & 20.8 & 76.0 \\
\hline
\end{tabular}

Data are mean with SD $(\mathrm{n}=6) .{ }^{*} \mathrm{p}<0.05,{ }^{*} \mathrm{p}<0.01$ and $* * * \mathrm{p}<0.001$ upon comparing to control, one way ANOVA followed by Dunnett's test compared all vs control test.

at 125 and $250 \mathrm{mg} / \mathrm{kg}$ respectively (Table 2). The results were comparable to diclofenac sodium (standard, $10 \mathrm{mg} / \mathrm{kg}$ ) that displayed $87.4 \%$ at $\mathrm{p}<0.001$.

The analgesic activity in tail immersion assay of the extract at 125 and $250 \mathrm{mg} / \mathrm{kg}$ was significant. A maximum analgesic response of $125 \mathrm{mg}$ extract was noted at $75 \mathrm{~min}$, latency increased $58.6 \%$, at $\mathrm{p}<0.01$. Similarly, the $250 \mathrm{mg}$ extract showed the maximum response of $60.7 \%,(\mathrm{p}<0.001)$ at $90 \mathrm{~min}$. whereas central analgesic, morphine demonstrated powerful activity at $60 \mathrm{~min}$ after treatment $84.8 \%$ at $\mathrm{p}<0.001$. Animals treated with naloxone produced a significant reduction in the analgesic activity of morphine and plant extract (125 and $250 \mathrm{mg} / \mathrm{kg}$ ) as shown in Table 3. The results from antagonistic assay reveal the possible participation of other receptors apart from opioid receptors.

\section{Formalin-induced paw licking}

The plant extract significantly inhibited both phases to $45.1 \%$ and, $61.75 \%(p<0.001)$ of for- malin-induced paw licking response respectively at $125 \mathrm{mg} / \mathrm{kg}$. Similarly, inhibition response of $250 \mathrm{mg} / \mathrm{kg}$ was observed as $53.2 \%(\mathrm{p}<0.001)$ and $69.9 \%(\mathrm{p}<0.001)$ as shown in Table 4. Animals pretreated with $10 \mathrm{mg} / \mathrm{kg}$ indomethacin caused a marked decline in the paw-licking time to $76.0 \%$ $(\mathrm{p}<0.001)$ in the second phase while the mild decline in licking time $(20.8 \%)$ in phase first was observed.

\section{Anti-inflammatory activity}

In the carrageenan-induced model for antiinflammatory assay, the test sample subdued formation of edema in a $3^{\text {rd }}$ hour at 100 and $200 \mathrm{mg}$, by $50.7 \%(\mathrm{p}<0.05)$ and $52.4(\mathrm{p}<0.05)$ respectively in a dose-dependent way. This effect was a bit maintained to the next hour followed by a decrease in the $5^{\text {th }}$ hour of the experiment. At the lowest dose (50 $\mathrm{mg}$ ) used, it showed $39.0 \%$ activity at $3^{\text {rd }} \mathrm{h}$ of the experiment as shown in Table 5. 


\section{DISCUSSION}

The present research work aims to find out antioxidant, analgesic, and anti-inflammatory potentials of S. adenotrichum. Important phenolic compounds were present in the extract as reported in our recent work (10). It was shown previously that gallic acid was present in the lyophilized extracts of Sedum telephium (19). Another study showed quantification of total glycosides of quercetin and kaempferol, but could not show the exact compounds (20). In a similar study, Oh et al. (21) also identified glycosides of quercetin and kaempferol in Sedum sarmentosum. These results suggest that different species of sedum are a good source of important phenolic compounds, especially flavonoids. The rise of the ROS level contributes to tissue injury and is potentially related to several diseases like cancer, aging, inflammation, and pain (22). In general, the creation, as well as biological reactivity of ROS, are under the control of catalase, glutathione peroxidase, and superoxide dismutase. However, if the creation of these free radicals is increased or the defense via antioxidant is decreased, it leads to oxidative stress (23), which can damage DNA, proteins, tissue, or lipids (24). Many studies have shown that many plant species are useful antioxidants. In this research study, the extract of the root showed excellent antioxidant activity in the highest used dose in DPPH and ABTS free radical scavenging activity. However, in the $\mathrm{H}_{2} \mathrm{O}_{2}$ free radical scavenging activity, it did not achieve the $\mathrm{IC}_{50}$ even at the highest dose used in the study.

Acetic acid-induced abdominal constriction method is thought to be a sensitive method and a weak analgesic can detect the results. The peripheral anal- gesic reaction is determined through this method. Acetic acid increases prostaglandin particularly $\mathrm{PGE}_{2}$ level in mice peritoneal fluid (25). Prostaglandins activate abdominal constriction through activation and sensitization of peripheral chemo-sensitive nociceptors (26), mainly related to inflammatory pain (27). Concerning this model of abdominal constriction, a significant analgesic response was observed from the results at both doses. This analgesic response may be due to its anti-inflammatory response because, in a visceral model of pain, arachidonic acid is released through cyclooxygenase and prostaglandin biosynthesis having a key role in nociception (28). So there may be involved an anti-inflammatory constituent in peripheral analgesic response which leads to inhibition of pain development.

Formalin-induced nociception is applied to determine the activity of the sample for relieving moderate persistent pain produced because of injury to the tissue (29). Acute and chronic phases of formalin-induced nociception demonstrate neurogenic and inflammatory pain respectively. The direct chemical motivation of afferent nociceptive fibers is linked with the acute phase which can be subdued by opioid analgesics such as morphine (30). The release of bradykinin, histamine, serotonin, and prostaglandins in peripheral tissues and functional changes in the dorsal horn of the spinal cord are linked with the $2^{\text {nd }}$ phase (31). The significant inhibition of both phases of formalin-induced nociception indicates that the inhibitory mechanism involves an effect on afferent fibers as well as on inflammatory mediators.

The tail immersion assay is employed for acute pain determination. This method involves spinal pathways in pain response regulation. Raised thermal noci-

Table 5. Effect of crude extract of Sedum adenotrichum on carrageenan-induced rats paws edema.

\begin{tabular}{|c|c|c|c|c|c|c|}
\hline Treatment & Dose & $1 \mathrm{st} \mathrm{h}$ & 2nd h & 3rd h & 4 th $\mathrm{h}$ & 5 th $\mathrm{h}$ \\
\hline Saline & $10 \mathrm{~mL}$ & $0.273 \pm 0.2$ & $0.261 \pm 0.02$ & $0.272 \pm 0.02$ & $0.256 \pm 0.02$ & $0.261 \pm 0.03$ \\
\hline Carragenaan & $50 \mu \mathrm{L}$ & $0.371 \pm 0.1 * * *$ & $0.423 \pm 0.03 * * *$ & $0.461 \pm 0.02 * * *$ & $0.472 \pm 0.02 * * *$ & $0.469 \pm 0.02 * * *$ \\
\hline Indomethacin & $10 \mathrm{mg}$ & $\begin{array}{c}0.209 \pm 0.04 * * \\
(43.6)\end{array}$ & $\begin{array}{c}0.172 \pm 0.03 * \\
(59.3)\end{array}$ & $\begin{array}{c}0.161 \pm 0.03 * * * \\
(65.0 \%)\end{array}$ & $\begin{array}{c}0.189 \pm 0.01 * * * \\
(59.9 \%)\end{array}$ & $\begin{array}{c}0.223 \pm 0.02 * * \\
(52.4 \%)\end{array}$ \\
\hline \multirow{5}{*}{ Extract } & 50 & $\begin{array}{c}0.276 \pm 0.03 * \\
(25.6 \%)\end{array}$ & $\begin{array}{c}0.266 \pm 0.02 * \\
(37.1 \%)\end{array}$ & $\begin{array}{c}0.281 \pm 0.02 * * \\
(39.0 \%)\end{array}$ & $\begin{array}{c}0.311 \pm 0.02 * \\
(34.1 \%)\end{array}$ & $\begin{array}{c}0.326 \pm 0.03 * \\
(30.4 \%)\end{array}$ \\
\cline { 2 - 7 } & 100 & $\begin{array}{c}0.250 \pm 0.02 * \\
(32.6 \%)\end{array}$ & $\begin{array}{c}0.238 \pm 0.01 * * \\
(43.7 \%)\end{array}$ & $\begin{array}{c}0.227 \pm 0.02 * * \\
(50.7 \%)\end{array}$ & $\begin{array}{c}0.254 \pm 0.03 * * * \\
(46.1 \%)\end{array}$ & $\begin{array}{c}0.291 \pm 0.03 * \\
(37.95 \%)\end{array}$ \\
\cline { 2 - 7 } & 200 & $\begin{array}{c}0.239 \pm 0.02 * * \\
(35.6 \%)\end{array}$ & $\begin{array}{c}0.227 \pm 0.02 * * \\
(46.3 \%)\end{array}$ & $\begin{array}{c}0.219 \pm 0.02 * * * \\
(52.4 \%)\end{array}$ & $\begin{array}{c}0.243 \pm 0.03 * * * \\
(48.5 \%)\end{array}$ & $\begin{array}{c}0.276 \pm 0.02 * * \\
(41.1 \%)\end{array}$ \\
\hline
\end{tabular}

Values as mean with SD $(\mathrm{n}=6) .{ }^{*} \mathrm{p}<0.05,{ }^{*} \mathrm{p}<0.01$ and $* * * \mathrm{p}<0.001$ upon comparing with control, one way ANOVA followed by Dunnett's: compared all vs control test. 
ception is used in this procedure and samples with good thermal antinociceptive results are considered as potent analgesics (32). The hot plate and tail-flick procedures are thought to be specific tests for central pain evaluation at the spinal and supraspinal levels (33) respectively. In this research work, there was a significant increase at both doses of the extract in the reaction. This increase in time of reaction because of the test sample suggests an analgesic response.

Carrageenan-induced edema involves the synthesis or release of mediators at the site of injury. Serotonin, bradykinins, histamine, and leukotrienes are these mediators, causing pain and fever also (34). Inhibitions of pharmacological effects or reaching of these mediators to the site of injury will normally improve inflammation and/ or symptoms. This work demonstrates that the tested sample possessed a significant antioedematogenic activity on carrageenaninduced paw edema. This is an appropriate in vivo experimental representation for anti-oedematous activity evaluation and is biphasic. During the first phase (1 h) histamine and serotonin are released and during the second phase (over $1 \mathrm{~h}$ ) the release of prostaglandins, products of cyclooxygenase, and kinins occur to provide continuity between the two phases (35).

Phenolic compounds and carotenoids are biologically active compounds that are presently under severe research study for exploring safe constituents of therapeutic value (36). For exploring therapeutically potent herbs and their constituents, this work was designed to explore the biological activities of the crude extract of $S$. adenotrichum. Preliminary, $S$. adenotrichum has tested positive for phenolic compounds and flavonoids presence. The analgesic and anti-inflammatory actions of S. adenotrichum may be attributed to these phenolic compounds and flavonoids identified using HPLC. Indomethacin reduces pain receptors sensitization caused by prostaglandins at the inflammatory site (37). The resulted analgesic and anti-inflammatory potentials of the test sample may be due to the overall actions of $S$. adenotrichum components affecting parallel to NSAID, in a complimentary way. Phenolic compounds present in plants possess significant antioxidant activity (38). Flavonoids such as kaempferol and quercetin showed promising anti-inflammatory activity $(39,40)$. The presence of these phenolic compounds in $S$. adenotrichum may thus be responsible for antioxidant and analgesic activities.

\section{CONCLUSION}

This research work shows that S. adenotrichum exhibits significant analgesic and anti-inflammatory effects, justifying its traditional use as a therapeutic agent. It is recommended to perform long-term studies to identify and isolate the active phytoconstituents involved in analgesic and anti-inflammatory effects and to reveal the real mechanism that is involved in analgesic and anti-inflammatory effects of the plant.

\section{Conflict of interest}

The authors declare that the research was conducted in the absence of any commercial or financial or non-financial relationships that could be construed as a potential conflict of interest.

\section{REFERENCES}

1. Pham-Huy L.A., He H., Pham-Huy C.: Int. J. Biomed. Sci. 4, 89 (2008).

2. Rao P.S., Kalva S., Yerramilli A., Mamidi S.: Free R 1. d. Antioxid. 1, 2 (2011).

3. Baradaran A., Madihi Y., Merrikhi A., Rafieian-Kopaei M., Nasri H.: Pak. J. Med. Sci. 29S, 354 (2013).

4. Olesen S.S., Juel J., Nielsen A.K., Frřkjćr J.B., Wilder-Smith O.H., et al.: Pancreatology 14, 497 (2014).

5. Al-Awaida W.J., Zihlif M.A., Al-Ameer H.J., Sharab A., Akash M., et al.: J. Food Biochem. 43, e12874 (2019).

6. Punchard N.A., Whelan C.J., Adcock I.: J. Inflamm. 1, 1 (2004).

7. Borges R., Nascimento M.V.M., de Carvalho A.A.V., Valadares M.C., de Paula J.R., et al.: Evid. Based Complementary Altern. Med. 2013, 715650 (2013).

8. Sarwar G.R., Qaiser M.: Pak. J. Bot. 44, 349 (2012).

9. Jung H-J., Kang H-J., Song Y.S., Park E-H., Kim Y-M., et al.: J. Ethnopharmacol. 116, 138 (2008).

10. Naz D., Muhamad A., Zeb A., Shah I.: Front. Nutr. 6, 177 (2019).

11. Vallčs J., Torrell M., Garnatje T., Garcia-Jacas N., Vilatersana R., et al.: Plant Biol. 5, 274 (2003).

12. Kumar K., Sharma Y.P., Manhas R., Bhatia H.: J. Ethnopharmacol. 170, 255 (2015).

13. Ali N., Aleem U., Shah S.W.A., Shah I., Junaid M., et al.: BMC Complement. Altern. Med. 13, 138 (2013).

14. Ahmad S., Zeb A., Ayaz M., Murkovic M.: Eur. Food Res. Technol. 246, 485 (2020).

15. Koster G.: Phys. Rev. 113, 445 (1959). 
16. Subash K., Britto G.F., Kumar K.S., Umamaheshwari A., Konda V.C.R.: Int. J. Basic Clin. Pharmacol. 7, 446 (2018).

17. Moniruzzaman M., Imam M.Z.: BMC Complement. Altern. Med. 14, 354 (2014).

18. Al-Ghamdi M.: J. Ethnopharmacol. 76, 45 (2001).

19. Bonina F., Puglia C., Tomaino A., Saija A., Mulinacci N., et al.: J. Pharm. Pharmacol. 52, 1279 (2000).

20. Ertaş A., Boğa M., Yılmaz M.A., Yeşil Y., Haşimi N., et al.: J. Agric. Food Chem. 62, 4601 (2014).

21. Oh H., Kang D-G., Kwon J-W., Kwon T-O., Lee S-Y., et al.: Biol. Pharm. Bull. 27, 2035 (2004).

22. Pinton P.: Oxid. Med. Cell. Long. 2013, 564961 (2013).

23. Kirk G.R., White J.S., McKie L., Stevenson M., Young I., et al.: J. Gastrointest. Surg. 10, 499 (2006).

24. Sharma P., Jha A.B., Dubey R.S., Pessarakli M.: J. Bot. 2012, 217037 (2012).

25. Deraedt R., Jouquey S., Delevallée F., Flahaut M.: Eur. J. Pharmacol. 61, 17 (1980).

26. Dirig D.M., Isakson P.C., Yaksh T.L.: J. Pharmacol. Exp. Therap. 285, 1031 (1998).

27. Bley K.R., Hunter J.C., Eglen R.M., Smith J.A.: Trends Pharmacol. Sci. 19, 141 (1998).
28. Trebino C.E., Stock J.L., Gibbons C.P., Naiman B.M., Wachtmann T.S., et al.: Proc. Nat. Acad. Sci. 100, 9044 (2003).

29. Oliveira R.R., Góis R.M., Siqueira R.S., Almeida J.R., Lima J.T., et al.: Rev. Bras. Farmacogn. 19, 672 (2009).

30. do Amaral J.F., Silva M.I.G., de Aquino Neto M.R.A., Neto P.F.T., Moura B.A., et al.: Biol. Pharm. Bull. 30, 1217 (2007).

31. Dalal A., Tata M., Allegre G., Gekiere F., Bons N., et al.: Neuroscience 94, 217 (1999).

32. Al Amin M., Chowdhury I.A., Mahbub K., Sattar M., Shahriar M., et al.: Bangladesh Pharm. J. 15, 171 (2012).

33. Marchioro M., Blank Md.F.A., Mourăo R.H.V., Antoniolli Â.R.: Fitoterapia 76, 637 (2005).

34. Adedapo A.A., Sofidiya M.O., Masika P.J., Afolayan A.J.: Basic Clin. Pharm. Toxicol. 103, 397 (2008).

35. Fernandes J.C., Spindola H., De Sousa V., Santos-Silva A., Pintado M.E., et al.: Mar. Drugs 8, 1763 (2010).

36. Zeb A., Haq A., Murkovic M.: Eur. Food Res. Technol. 245, 365 (2018).

37. Omoigui S.: Med. Hypotheses 69, 70 (2007).

38. Zeb A.: J. Food Biochem. 44, e13394 (2020).

39. Imran M., Rauf A., Shah Z.A., Saeed F., Imran A., et al.: Phytother. Res. 33, 263 (2019).

40. Zhu Y., Yu J., Jiao C., Tong J., Zhang L., et al.: Heliyon 5, e02374 (2019).

C 2020 by Polish Pharmaceutical Society. This is an access article under the CC BY NC license (http://creativecommons.org/licenses/by-nc/4.0/). 